\title{
Characterization and Decant of Tank 42H Sludge Sample ESP-200
}

by

M. S. Hay

Westinghouse Savannah River Company

Savannah River Site

Aiken, South Carolina 29808.

N. E. Bibler

DOE Contract No. DE-AC09-96SR18500

This paper was prepared in connection with work done under the above contract number with the U. S.

Department of Energy. By acceptance of this paper, the publisher and/or recipient acknowledges the U. S.

Government's right to retain a nonexclusive, royalty-free license in and to any copyright covering this paper, along with the right to reproduce and to authorize others to reproduce all or part of the copyrighted paper. 


\section{DISCLAIMER}

This report was prepared as an account of work sponsored by an agency of the United States Government. Neither the United States Government nor any agency thereof, nor any of their employees, makes any warranty, express or implied, or assumes any legal liability or responsibility for the accuracy, completeness, or usefulness of any information, apparatus, product or process disclosed, or represents that its use would not infringe privately owned rights. Reference herein to any specific commercial product, process or service by trade name, trademark, manufacturer, or otherwise does not necessarily constitute or imply its endorsement, recommendation, or favoring by the United States Government or any agency thereof. The views and opinions of authors expressed herein do not necessarily state or reflect those of the United States Government or any agency thereof.

This report has been reproduced directly from the best available copy.

Available for sale to the public, in paper, from: U.S. Department of Commerce, National Technical Information Service, 5285 Port Royal Road, Springfield, VA 22161, phone: (800) 553-6847

fax: (703) 605-6900

email: orders@ntis.fedworld.gov

online ordering: http://www.ntis.gov/ordering.htm

Available electronically at http://www.doe.gov/bridge

Available for a processing fee to U.S. Department of Energy and its contractors, in paper, from: U.S. Department of Energy, Office of Scientific and Technical Information, P.O. Box 62, Oak Ridge, TN 37831-0062, phone: (865) 576-8401

fax: (865) 576-5728

email: reports@adonis.osti.gov 


\section{DISCLAIMER}

\section{Portions of this document may be illegible in electronic image products. Images are produced from the best available original document.}


Keywords: Supernate Composition Sludge Composition

High Level Waste

Retention Time: Permanent

INFORMATION ONLY

RECORDS ADMINISTRATION

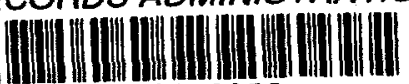

$\mathrm{R} 0078358$

Characterization and Decant of Tank 42H Sludge Sample ESP-200

M.S. Hay

N. E. Bibler

Publication Date: June 12, 1998

Westinghouse Savannah River Company Savannah River Technology Company Aiken, SC 29808

Prepared for the U. S. Department of Energy under Contract No. DE-AC09-69SAT6855-

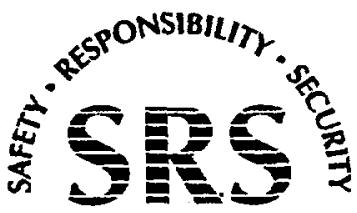


WSRC-RP-98-00406

Page 2 of 24

Authors
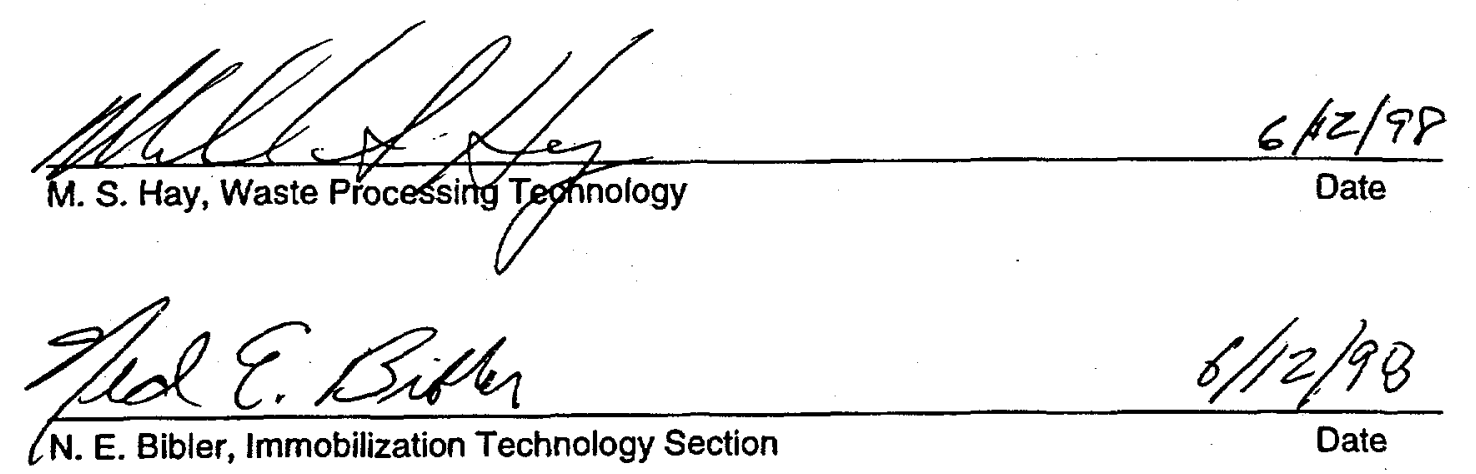

Design Check

$\frac{\text { Darrel D. Walker }}{\text { D. D. Walker, Waste Processing Technology }} \frac{6 / 12 / 98}{\text { Date }}$

Approvals/Review
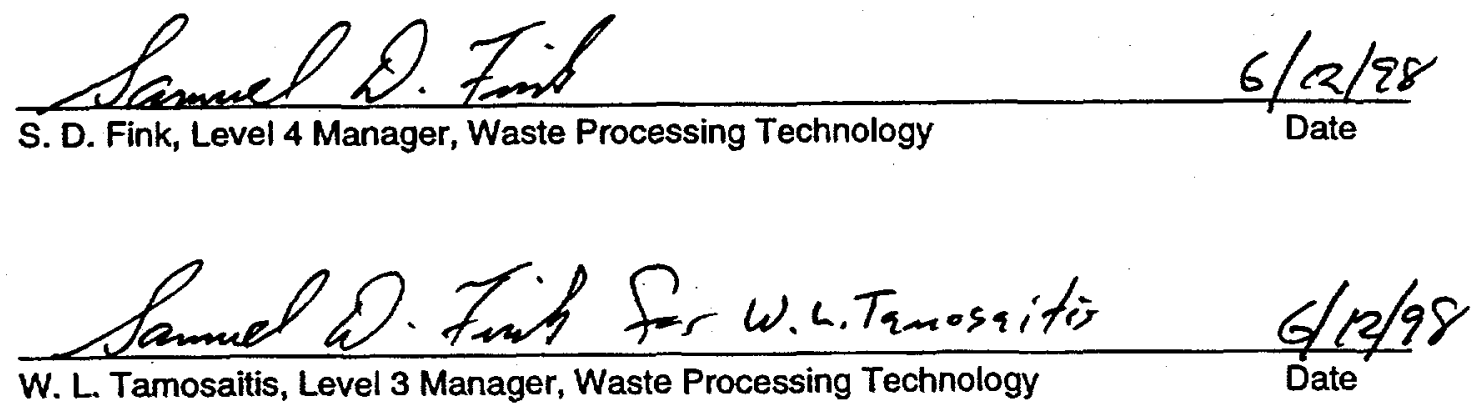


\section{Summary}

DWPF Engineering requested that the Savannah River Technology Center (SRTC) provide a demonstration of the DWPF flowsheet on sludge from Tank $42 \mathrm{H}$ in the Shielded Cell facility. A 5 liter sample of the Tank 42H sludge (ESP-200), obtained with the tank contents fully mixed, arrived at SRTC on January 20,1998. This report details receipt of the 5 Liter sample at SRTC, the decant of the sample, and the characterization of the pre- and post-decant Tank $42 \mathrm{H}$ sludge.

Evaluation of the measured composition of the supernate indicates Sample ESP-200 became diluted approximately $20 \%$ by volume prior to receipt. This dilution complicates the relationship of the characterization of Post-Decant ESP-200 to the current contents of Tank 42H. For the purposes of modeling the current tank contents of Tank $42 \mathrm{H}$, this report provides an estimated composition based on analytical data of recent samples from Tank $42 \mathrm{H}$.

\section{Introduction}

The Defense Waste Processing Facility (DWPF) currently operates on a Sludge-Only flowsheet with feed from Tank $51 \mathrm{H}$. Less than half of the initial amount of sludge in Tank $51 \mathrm{H}$ remains after approximately 2 years of processing. To provide continuous feed to DWPF, future operations will blend sludge from Tank $42 \mathrm{H}$ into the sludge remaining in Tank $51 \mathrm{H}$. Before the transfer, Operations will decant excess supernate from the sludge in Tank $42 \mathrm{H}$. DWPF Engineering requested that the Savannah River Technology Center (SRTC) provide a demonstration of the DWPF Sludge-Only flowsheet on sludge from Tank $42 \mathrm{H}$ in the Shielded Cell facility. In addition, since the sample was obtained before decanting excess supernate from Tank 42H, DWPF requested the sludge sample be characterized and decanted to closely model expected ESP operations.

For the purpose of the demonstration, a 5 liter sample of the Tank $42 \mathrm{H}$ sludge, obtained with the tank contents fully mixed, was sent to SRTC on January 20,1998. The sample was designated ESP-200. Sample analysis complied with the Task Plan ${ }^{2}$ and Analytical Study Plan. ${ }^{3}$ The measured composition of the as-received sample and the Sludge Washing Model ${ }^{4}$ allow one to determine the volume of supernate to remove to simulate the expected decant in the Extended Sludge Processing (ESP) facility. After decanting, the resulting sludge was characterized again before starting the demonstration of the DWPF Sludge-Only flowsheet.

This document reports the receipt of the 5 liter sample at SRTC, the decant of the sample, and the determination of the pre- and post-decant compositions of the sample.

\section{Experimental}

Analytical Development Section (ADS) performed all analytical measurements) with the exception of weight percent solids and density measurements conducted in the Shielded Cells.

\section{Weight Percent Solids Analysis}

The weight percent of total solids in the sludge were measured using a conventional drying oven at $100^{\circ} \mathrm{C}$ and stainless steel or Teflon beakers. The weight percent of dissolved solids in a sample of the filtered supernate were measured in the same manner. The weight percent insoluble solids and soluble solids in the sludge were calculated from the measurements of the weight percent total solids of the sludge and the weight percent dissolved solids in the supernate. Obtaining the weight percent solids analysis of sludge samples in this manner avoids difficulties associated with reproducibly measuring the insoluble solids directly. Equations 1 and 2 allow calculation of the weight percent of insoluble and soluble solids. The weight percent of soluble solids gives the mass of the dissolved solids in the supernate expressed as a percentage of the mass of the sludge sample. The weight 
percent of insoluble solids represents the mass of insoluble solids expressed as a percentage of the mass of the sludge sample.

$$
\begin{array}{ll}
w_{d s}=\text { weight fraction of dissolved solids } & \text { (wt dissolved solids/ wt of supernate) } \\
w_{t s}=\text { weight fraction of total solids } & \text { (wt total solids/ } w t \text { of sludge slurry) } \\
w_{\text {is }}=\text { weight fraction of insoluble solids } & \text { ( } w \text { insoluble solids/ wt of sludge slurry) } \\
w_{\text {ss }}=\text { weight fraction of soluble solids } & \text { (wt dissolved solids/ wt of sludge slurry) } \\
w_{\text {is }}=\left(w_{t s}-w_{d s}\right) /\left(1-w_{d s}\right) & \text { Eq. } 1 \\
w_{S s}=w_{t s}-w_{i s} & \text { Eq. } 2
\end{array}
$$

A $15 \mathrm{wt} \%$ or a $1 \mathrm{wt} \% \mathrm{NaCl}$ standard solution was measured concurrently during the analysis of the sludge and supernate samples. During the course of these measurements, tests found that a high bias can result from use of aluminum vessels or glass fiber pads when measuring high pH solutions. For this reason, all weight percent solids measurements used stainless steel or Teflon beakers.

\section{Density Measurements}

Density measurements were made on both the sludge and the filtered supernate using a pipette tip in with the small end heat-sealed. After heat sealing, these pipette tips provide a reproducible volume of $8.25 \mathrm{~mL}$. The sludge does not wet the pipette tips eliminating problems with entrained air bubbles when filling a narrow cylinder with thick sludge.

\section{Determination of the Calcine Conversion Factor}

Two samples of the Post-Decant ESP-200 sludge slurry having known weight were calcined to 1000 ${ }^{\circ} \mathrm{C}$ to allow determination of the conversion factor from a weight percent total dried solids basis to weight percent calcined solids basis. Dividing the previously measured weight percent total dried solids $\left(100^{\circ} \mathrm{C}\right)$ by the weight percent calcined solids $\left(1000^{\circ} \mathrm{C}\right)$ yields the calcine conversion factor. Once can convert the concentration of an element in the sludge expressed as a weight percent of the total dried solids to a weight percent calcine basis by dividing by the calcine conversion factor.

\section{Sample Preparation}

A 5 to 10-fold dilution with deionized, distilled water was generally necessary to lower the radiation levels on supernate samples before submittal to ADS for analysis. Dissolution of samples of dried sludge solids were performed in quadruplicate by contacting with aqua-regia or by fusion with sodium peroxide. Contacting the sodium peroxide fusion with nitric acid allows determination of the composition of the total sample. Water uptake of the sodium peroxide fusion was used to determine the total phosphate and sulfate in the sludge. The digested sludge samples were diluted to $250 \mathrm{~mL}$ with deionized, distilled water before analysis. Quality control included dissolving a glass standard concurrently with the sludge samples and submitting for analysis. An ICP-ES standard containing 100 $\mathrm{mg} / \mathrm{L}$ of several metals of interest (nitric acid matrix) also accompanied all samples. The analytical results of the standards indicated complete dissolution methods and accurate analyses.

\section{Analytical Methods}

ADS uses the following analytical methods for determination of specific species. Nitrate, nitrite, sulfate, oxalate and phosphate were measured by ion chromatography (IC). Chloride and fluoride were determined by the ion selective electrode (ISE) method. Aluminate, carbonate, and hydroxide were measured using a titration method employing $\mathrm{BaCl}_{2}$ to precipitate carbonate allowing the determination of all three species. Sodium, aluminum, and iron, as well as other metallic elements, were measured using inductively-coupled plasma-emission spectroscopy (ICP-ES). Potassium and mercury were measured using atomic adsorption spectroscopy (AA) with mercury determined using the cold-vapor technique (CV). Gamma emitting fission products were measured using gamma 
spectroscopy. Actinides were determined by a combination of inductively-coupled plasma mass spectrometry (ICP-MS) and alpha counting spectroscopy. $\mathrm{Sr}^{\circ}$ was determined from the beta liquid scintillation counting. Strontium separation was performed on selected samples as necessary.

\section{Preparation of the Decanted Sludge}

After mixing the tank containing the 5 liter sample for 1 hour a 2 liter aliquot was pumped into a volume calibrated 3 liter polyethylene bottle. The 2 liters of sludge settled undisturbed. After approximately 2 weeks, the sludge solids settled to approximately $1 / 2$ the total volume of the sample. A pump was used to remove $654 \mathrm{~mL}$ of supernate from the settled sludge. The decanted supernate was pumped into a graduated cylinder to allow accurate measurement of the volume of supernate removed. The settled sludge was mixed and a sample removed for analysis. The sample was dried and the total dried solids dissolved in quadruplicate by two methods.

\section{Receipt of the Tank $42 \mathrm{H} 5$ Liter Sample}

A 5 liter sample of Tank 42H sludge (sample ID: ESP-200) arrived at SRTC on January 20, 1998. The sample was obtained from Tank $42 \mathrm{H}$ after thoroughly mixing the tank and lowering the sampler into the middle of the slurry. Approximately 3 liters of thick slurry resided in the body of the sampler with approximately 2 liters of supemate containing sludge solids found in the secondary container. ${ }^{5}$ Subsequent testing found the sampler contained a leak through a cover plate. A decision was made to combine the two parts of the sample based on the following information.

- Tank Farm personnel involved in the sampling expressed concern that the sampler might be leaking.

- The combined volume of the two fractions of the sample agreed with the volume of sampler body.

- The sample contained in the body of the sampler appeared to have a very thick consistency and the fraction in the secondary container contained a significant amount of sludge solids.

The material in the body of the sampler was emptied into a small stainless steel tank in the Shielded Cells. The material in the secondary container was mixed to suspend the solids and pumped into the same tank. No rinse water was used to remove the sludge from the sampler or the secondary container. Visual inspection of the secondary container found negligible sludge residue remained after the transfer. The volume of sludge removed from the sampler and the secondary container was $4.8 \mathrm{~L} \pm 200 \mathrm{~mL}$. Samples of the supernate and dissolutions of the total dried solids from the combined sludge slurry were sent to ADS for characterization.

\section{Characterization of As Received ESP-200 Slurry Sample}

Tables 1 and 2 show the composition of the Pre-Decant ESP-200. Table 1 gives the weight percent solids and density measurements on the Pre-Decant ESP-200. The table also lists the composition of ESP-190, a slurry dip sample obtained in September of 1997, for comparison. ${ }^{6}$ Table 2 provides a comparison of the major components of the supernates and total dried solids from Pre-Decant ESP200 and ESP-190. (Tables 6 and 7 provide a more detailed analysis for Pre-Decant ESP-200.)

The weight percent dissolved solids data in Table 1 and the supernate compositions in Table 2 indicate dilution of ESP-200 relative to ESP-190. From the supernate data in Table 2, the dilution of ESP-200 appears approximately $20 \%$ by volume. Although an error of $\pm 15 \%$ exists for analytical measurement on samples from HLW tanks, the values in ESP-190 supernate prove consistently higher than ESP-200. The dilution value of $20 \%$ derives from the average difference in the concentration of the major species in the supernate $\left(\left[\mathrm{Na}^{+}\right],\left(\mathrm{NO}_{3}\right]_{3}\left[\mathrm{NO}_{2}\right],[\mathrm{OH}],\left[\mathrm{CO}_{3}{ }^{2}\right]\right)$ and the 
weight percent dissolved solids for ESP-200 and ESP-190. A slurry dip sample (ESP-199) was obtained from Tank 42H at the same time as the 5 liter sample (ESP-200). The composition of ESP. 199 supernate agrees with ESP-190 indicating that ESP-200 has indeed been diluted. ${ }^{8}$ The source of the dilution water remains unknown.

The analytical results on Pre-Decant ESP-200 appear self-consistent. When corrected for dilution, the results from Pre-Decant ESP-200 agree with ESP-190. The anion/cation balance in the supernate exceeds $95 \%$. With the composition of the Pre-Decant ESP-200 established, development of a decant strategy to match the expected decant in ESP proceeded.

\section{Decant Strategy}

The development of a decant strategy for sample ESP-200 became more complex due to the inadvertent dilution of the sample. The decant strategy assumed that ESP would decant Tank $42 \mathrm{H}$ to a maximum level of 110 inches ${ }^{9}$ and that sample ESP-190 (Sept. 1997 dip sample) provided the best representation of the current composition of the tank. ${ }^{10} \mathrm{The}$ assumptions seemed reasonable given the supernate compositions from the last three dip samples -- ESP-190, ESP-191 (October of 1997) $^{10}$, and ESP-199 (January of 1998) - from Tank 42H showed good agreement. In addition, the concentration of the major elements of the total dried solids in ESP-190 agreed with a sludge sample obtained from Tank $42 \mathrm{H}$ in October of 1992. ${ }^{12}$ The target decant level for Tank $42 \mathrm{H}$ was 90 to 110 inches. ${ }^{8}$ For the Shielded Cells demonstration, a decant level of 110 inches in Tank $42 \mathrm{H}$ was simulated on the basis that the higher tank level ( less supernate decanted) introduces conservatism with respect to glass properties and processing.

The Sludge Washing Model was used to estimate the composition of Tank $42 \mathrm{H}$ decanted to 110 inches based on a starting composition of sample ESP-190. The decanted composition was then used as the target for decanting the 2 liter aliquot of sample ESP-200 for use in the SRTC demonstration. Table 3 shows the projected composition of Tank $42 \mathrm{H}$ decanted to 110 inches based on a starting composition of sample ESP-190.

Compositional differences between samples ESP-190 and ESP-200 presented difficulties in matching the decanted composition of ESP-200 to that estimated for Tank $42 \mathrm{H}$. These differences in the compositions of include the following.

- The $-20 \%$ dilution of sample ESP-200 results in a lower solids content for a given volume relative to Sample ESP-190.

- Sampie ESP-200 has a lower ratio of soluble to insoluble solids than sample ESP-190

- The weight percent insoluble sodium in sample ESP-200 appears lower than sample ESP. 190.

Because of the differences in the compositions, the decant strategy sought to provide the same or slightly greater equivalents of components in the slurry that effect key processing parameters in DWPF. These components include species affecting hydrogen generation (i.e., $\mathrm{OH}, \mathrm{NO}_{2}{ }^{\circ}, \mathrm{NO}_{3}$; $\mathrm{CO}_{3}{ }^{-}$) and glass quality (i.e., $\mathrm{Na}, \mathrm{Al}, \mathrm{Fe}$ ).

Based on the analysis of several different decanting scenarios, the best alternative involved decanting the 2 liter aliquot of sample ESP-200 to 1.35 liters. Table 4 shows the projected composition of the decanted material. This composition provides equal or greater base equivalents, nitrate and nitrite equivalents, sodium equivalents, and mass of sludge solids. Due to the extra water in sample ESP-200, a larger volume of the slurry was needed relative to the estimated Tank $42 \mathrm{H}$ slurry to provide the same or greater equivalents of important components. 


\section{Characterization of Post-Decant ESP-200 Sludge}

After decanting the 2 liter aliquot of sample ESP-200 sludge, samples of the supernate and total dried solids were submitted for characterization of both radioactive and non-radioactive species. Tables 5 through 8 list the results of the characterization of the Post-Decant ESP-200 sample. Some of the tables also list the composition of a 25 liter sludge sample of Tank $42 \mathrm{H}$ obtained in 1992 for comparison. ${ }^{12}$ The 1992 sample was the last Tank $42 \mathrm{H}$ sample to undergo a complete characterization. Some tables also provide the composition of the Pre-Decant ESP-200 sludge for reference.

In Table 5, the weight percent total solids of the decanted sludge $(16.0 \mathrm{wt} \%)$ closely matches the value predicted by the Sludge Washing Model for the decant (16.1 wt \%). The small difference in the weight percent dissolved solids of the supernate between the Pre- and Post-Decant sample are attributable to analytical error. Table 5 also gives a calcine conversion factor. The calcine conversion factor resulted from drying a sample of Post-Decant ESP-200 to $1000^{\circ} \mathrm{C}$. The ratio of the weight percent calcined solids to the weight percent total dried solids yields a calcine conversion factor. One can convert the concentration of an element in the sludge expressed as a weight percent of the total dried solids to a weight percent calcine basis by multiplying by the calcine conversion factor.

Theoretically, the supernate compositions of the Pre-Decant and Post-Decant ESP-200 sludge listed in Table 6 should equate. The differences prove small and attributable to analytical error.

The composition of the total dried solids in the Post-Decant ESP-200, listed in Table 7 and 8, agrees with previous measurements from the 1992 sludge sample and with the measured Pre-Decant ESP200 composition. As expected after decanting, insoluble species show a slight increase in concentration due to the removal of soluble salt.

The total phosphate and total sulfate were also measured in the Post-Decant ESP-200. The results indicate that essentially all of the sulfate is soluble with all of the phosphate insoluble. The phosphate and sulfate results agree with previous analyses made on the 1992 Tank $42 \mathrm{H}$ sludge sample.

A portion of the Post-Decant ESP-200 sludge was placed in a filter and washed with a large volume of inhibited water. Table 9 shows the composition of the resulting solids. The weight percent insoluble sodium matches previous measurements of Tank $42 \mathrm{H}$ and $51 \mathrm{H}$ sludge that found $-3 \mathrm{wt} \%$ insoluble sodium. In the far right column of Table 9 , the ratio of the weight percent insoluble solids to the weight percent total dried solids equals -1.15 for most of the species listed. A lower ratio exists for some species indicating some solubility in the wash solutions.

\section{Relationship of Post-Decant ESP-200 to the Current Contents of Tank $42 \mathrm{H}$}

The observed dilution of the as received ESP-200 sample obscures the relationship of the characterization of Post-Decant ESP-200 to the current contents of Tank 42H. Also, the decant of the 2 liter aliquot of sample ESP-200 in the Shielded Cells assumed decanting Tank $42 \mathrm{H}$ to 110 inches. Operations actually decanted Tank $42 \mathrm{H}$ to 100 inches. Fortunately, Tank $42 \mathrm{H}$ contains a fairly dilute supernate so the removal of an extra 10 inches of supernate does not largely alter the bulk sludge composition. The biggest difference in the composition of the Post-Decant ESP-200 and the current contents of Tank $42 \mathrm{H}$ involves the weight percent total solids of the slurry due to the dilution of sample ESP-200.

Table 10 shows the estimated composition of Tank $42 \mathrm{H}$ assuming a starting composition matching ESP-190 and matching ESP-200 each decanted to 100 inches using the Sludge Washing Model. The third column lists the measured composition of Post-Decant ESP-200 for comparison. The 
composition of the ESP-200 case includes adjustment to remove the dilution water. As seen in the table, the decanted compositions of the two cases do not differ markedly from the measured composition of Post-Decant ESP-200 with the exception of weight percent solids values.

Table 11 lists the recommended values for use in estimating the current composition of Tank $42 \mathrm{H}$. The supernate composition should not be changed by decanting the tank. The estimated supernate composition is the result of averaging the compositions of the three previous dip samples (ESP-190, ESP-191, ESP-199) from Tank 42H. Complete supemate analyses were not conducted on all three samples. Therefore, not all of the values are the average of three measurements. For example, the $U$, $\mathrm{Pu}$, and $\mathrm{Sr}^{90}$ were only measured in ESP-191.

The estimated composition of the total dried solids in Table 11 were taken from the measured composition of Post-Decant ESP-200 (Tables 6-8). The weight percent solids and specific gravity of the sludge were taken from the estimated composition of ESP-190 decanted to 100 inches (Table 10).

\section{Quality Assurance}

Sample identification within the Shielded Cells conformed with Procedure 2.21, "Radioactive Sample Receiving, Labeling, and Tracking," of the L1 Manual. Laboratory notebooks WSRC-NB-97-00513, WSRC-NB-98-00082, and WSRC-NB-98-00083 record all data from the study.

\section{Acknowledgements}

The authors thank the following individuals and organizations who contributed to the successful and timely completion of this program. Ron Blessing spent many hours preparing the $5 \mathrm{~L}$ sludge sampler/cask as well as coordinating with and training ITP/ESP operations personnel. All of the Shielded Cells personnel and particularly those in A-Block deserve special praise for their highly skilled use of remote manipulators performing the experimental work and sample preparation. Chuck Coleman and other ADS personnel provided exceptional analytical support. The "125 Day Campaign" team made up of Terry Fellinger, Kathy Marshall, Charles Crawford, and Dan Lambert provided technical support and insights in our many discussions. 
WSRC-RP-98-00406

Page 9 of 24

\section{References}

1. S. L. Marra, "Technical Task Request", HLW/DWPF/TTR-970139, Rev. 1, January 1, 1998.

2. T. L. Fellinger, "Technical and QA Plan for the HLW/DWPF/TTR-970139: Confirmation Run of Tank 42 Radioactive Sludge and Frit 200 in the Shielded Cells (U)", WSRC-RP-97-00970, Rev. 0, January 21, 1998.

3. K. M. Marshall, N. E. Bibler, T. L. Fellinger, M. S. Hay, and C. L. Crawford, "Analytical Study Plan: Batch Characterization - Tank 42 Radioactive Sludge Demonstration in the Shielded Cells (U)", WSRC-TR-97-00387, Rev. 0, January 27, 1998.

4. M. S. Hay, "Revised Sludge Washing Model and Verification of Computational Accuracy (U)", WSRC-RP-93-841, June 22, 1993.

5. T. L. Fellinger, K. M. Marshall, C. L. Crawford, M. S. Hay, and N. E. Bibler, "HLW/DWPF/TTR-970139: Receipt of the 5 Liter Tank 42 Radioactive Sludge Sample - ESP$200(\mathrm{U})^{n}$ SRT-VTB-98-002, February 5, 1998.

6. M. S. Hay, "Analytical Results for Tank 42H Sample ESP-190", SRT-LWP-97-135, November $11,1997$.

7. M. S. Hay and T. B. Edwards, "Statistical Analysis of ESP Verification Test Samples (U)", WSRC-RP-94-1224, November 4, 1994.

8. M. S. Hay, "Analytical Results for Tank 42H Sample ESP-199 (U)", SRT-LWP-98-0033, February 27, 1998.

9. H. H. Elder, E. D. Lee, W. D. Kerley, and M. S. Miller, "Engineering Path Forward S-PF-980005 Decanting Tank 42 and Decanting the Tank 42 Five Liter Sludge Qualification Sample (U)", HLW-DEN-980019, January 26, 1998.

10. M. S. Hay, N. E. Bibler, T. L. Fellinger, K. M. Marshall, and C. L. Crawford, "Decant Strategy for Tank 42H Sludge Demonstration", SRT-LWP-98-0032, February 27, 1998.

11. M. S. Hay, "Analytical Results for Tank 42H Sample ESP-191 (U)", SRT-LWP-97-153, December 17, 1997.

12. M. S. Hay and N. E. Bibler, "Characterization and Sludge Washing of Tank 42H Sludge (U)", WSRC-RP-94-730, July 27, 1994. 
Table 1. Results of the Weight Percent Solids and Density Measurements for the Pre-Decant ESP-200 and ESP-190 Tank 42H Sludge Samples.

\begin{tabular}{lcc}
\multicolumn{1}{c}{ Species } & $\begin{array}{c}\text { Pre-Decant } \\
\text { ESP-200 Sludge }\end{array}$ & $\begin{array}{c}\text { ESP-190 } \\
\text { Sludge* }\end{array}$ \\
\hline wt \% Dissolved Solids & 2.07 & 2.68 \\
wt \% Soluble Solids & 1.86 & 2.39 \\
wt \% Insoluble Solids & 9.94 & 10.7 \\
wt \% Total Solids & 11.8 & 13.1 \\
Sp. g. (slurry) & 1.08 & 1.09 \\
Sp. g. (supernate) & 1.02 & 1.02
\end{tabular}

*The values for ESP-190 come from reference 6. 
WSRC-RP-98-00406

Page 11 of 24

Table 2. Analytical Results of the Pre-Decant ESP-200 and ESP-190 Tank $42 H$ Slurry Sample.

\begin{tabular}{|c|c|c|c|}
\hline Species & & $\begin{array}{c}\text { Pre-Decant } \\
\text { ESP-200 Slurry } \\
\end{array}$ & $\begin{array}{c}\text { ESP-190 } \\
\text { Slurry* }\end{array}$ \\
\hline \multicolumn{4}{|c|}{ Supernate Analysis } \\
\hline$\left[\mathrm{NO}_{3}^{-}\right]$ & $\mathbf{M}$ & $0.038(10)$ & 0.050 \\
\hline$\left[\mathrm{NO}_{2}^{-}\right]$ & $M$ & $0.18(8.5)$ & 0.20 \\
\hline$\left[\mathrm{SO}_{4}{ }^{2 \cdot}\right]$ & $M$ & $0.007(12)$ & 0.009 \\
\hline$\left[\mathrm{C}_{2} \mathrm{O}_{4}{ }^{2-}\right]$ & M & $0.003(1.1)$ & 0.004 \\
\hline$\left[\mathrm{CO}_{3}{ }^{2 \cdot}\right]$ & $M$ & $0.051(1.7)$ & 0.064 \\
\hline$\left[\mathrm{AlO}_{2}^{-}\right]$ & M & $0.003(4.2)$ & 0.004 \\
\hline$\left[\mathrm{OH}^{-}\right]_{\text {free }}$ & $M$ & $0.022(3.1)$ & 0.031 \\
\hline$[\mathrm{Cl}]$ & $M$ & $0.001(22)$ & 0.001 \\
\hline$[F]$ & $M$ & $0.002(3.4)$ & 0.003 \\
\hline $\mathrm{Na}$ & $M$ & $0.38(0.3)$ & 0.44 \\
\hline $\mathrm{Cs}^{137}$ & $\mu \mathrm{Ci} / \mathrm{mL}$ & $2.30(6.1)$ & 2.88 \\
\hline \multicolumn{4}{|c|}{ Total Dried Solids Analysis } \\
\hline $\mathrm{Fe}$ & wt \% & $20.1(4.0)$ & 18.4 \\
\hline $\mathrm{Na}$ & $w t \%$ & 7.99 (3.6) & 9.41 \\
\hline Al & wt $\%$ & $7.49(5.7)$ & 6.97 \\
\hline $\mathrm{Mn}$ & wt \% & $3.46(3.8)$ & 3.18 \\
\hline $\mathrm{Ca}$ & wt $\%$ & $2.15(4.3)$ & 2.32 \\
\hline $\mathrm{Mg}$ & wt $\%$ & $1.12(4.2)$ & 1.06 \\
\hline
\end{tabular}

Value in parenthesis indicates percent relative standard deviation of four or more determinations on aliquots of the same sample. This value provides a measure of the analytical precision and does not account for the sampling uncertainty.

"The values for ESP-190 come from reference 6. 
Table 3. Composition of ESP-190 Slurry Dip Sample from Tank 42H and Estimated Composition Decanted to 110 inches.

\begin{tabular}{llcc}
\multicolumn{1}{c}{ Species } & wt \% & $\begin{array}{c}\text { Measured } \\
\text { Composition of } \\
\text { ESP-190* }\end{array}$ & $\begin{array}{c}\text { Estimated Composition of } \\
\text { ESP-190 } \\
\text { Decanted to 110 In. }\end{array}$ \\
\hline $\mathrm{Na}$ & $w 1 \%$ & 18.4 & 7.36 \\
$\mathrm{Fe}$ & $w t \%$ & 6.97 & 19.8 \\
$\mathrm{Al}$ & $w t \%$ & 3.18 & 7.51 \\
$\mathrm{Mn}$ & $w t \%$ & 2.32 & 3.43 \\
$\mathrm{Ca}$ & $w t \%$ & 1.06 & 2.50 \\
$\mathrm{Mg}$ & $w t \%$ & 1.20 & 1.14 \\
$\mathrm{Si}$ & $w t \%$ & 0.66 & 1.30 \\
$\mathrm{P}$ & $w t \%$ & 0.37 & 0.71 \\
$\mathrm{Ni}$ & $w t \%$ & 0.14 & 0.40 \\
$\mathrm{Cr}$ & & & 0.17 \\
& & 13.1 & 18.5 \\
wt \% Total Solids & & 2.68 & 2.68 \\
wt \% Dissolved Solids & & 10.7 & 16.3 \\
wt \% Insoluble Solids & & 2.39 & 2.15 \\
wt \% Soluble Solids & & &
\end{tabular}

*The values for ESP-190 come from reference 6. 
WSRC-RP-98-00406

Page 13 of 24

Table 4. Comparison of the Estimated Decanted Compositions of ESP-200 and ESP-190.

\begin{tabular}{llcc} 
& & $\begin{array}{c}\text { Estimated Composition of } \\
\text { ESP-190 } \\
\text { Decanted to 110 in. }\end{array}$ & $\begin{array}{c}\text { Estimated Composition of } \\
\text { Decanted } \\
\text { ESP-200 Sludge* }\end{array}$ \\
\hline $\mathrm{Na}$ & wt \% & 7.36 & 6.06 \\
$\mathrm{Fe}$ & $w t \%$ & 19.8 & 21.8 \\
$\mathrm{Al}$ & $w t \%$ & 7.51 & 7.92 \\
$\mathrm{Mn}$ & $w t \%$ & 3.43 & 3.65 \\
$\mathrm{Ca}$ & $w t \%$ & 2.50 & 2.28 \\
$\mathrm{Mg}$ & $w t \%$ & 1.14 & 1.18 \\
$\mathrm{Si}$ & $w t \%$ & 1.30 & 1.38 \\
$\mathrm{P}$ & $w t \%$ & 0.71 & 0.85 \\
$\mathrm{Ni}$ & $w t \%$ & 0.40 & 0.34 \\
$\mathrm{Cr}$ & $w t \%$ & 0.17 & 0.13 \\
& & & 16.1 \\
wt \% Total Solids & & 18.5 & 2.07 \\
wt \% Dissolved Solids & & 2.67 & 14.3 \\
wt \% Insoluble Solids & & 16.3 & 1.72 \\
wt \% Soluble Solids & & 2.15 &
\end{tabular}

*ESP-200 decanted to the equivalent of ESP-190 decanted to 110 inches. 
Table 5. Results of the Weight Percent Solids and Density Measurements for the Pre-Decant and Post-Decant Tank 42H Sludge Sample ESP-200.

\begin{tabular}{lcc}
\multicolumn{1}{c}{ Species } & $\begin{array}{c}\text { Pre-Decant } \\
\text { ESP-200 }\end{array}$ & $\begin{array}{c}\text { Post-Decant } \\
\text { ESP-200 }\end{array}$ \\
\hline wt \% Dissolved Solids & 2.07 & 2.29 \\
wt \% Soluble Solids & 1.86 & 1.97 \\
wt \% Insoluble Solids & 9.94 & 14.1 \\
wt \% Total Solids & 11.8 & 16.0 \\
Sp. g. (slurry) & 1.08 & 1.13 \\
Sp. g. (supernate) & 1.02 & 1.02 \\
Calcine Conversion & & 0.79 \\
Factor* & &
\end{tabular}

"The calcine conversion factor allows converting sludge concentrations from a weight percent total dried solids basis to a weight percent calcined solids basis by multiplying by the calcine conversion factor. 
Table 6. Analytical Results of the Pre-Decant and Post-Decant Tank 42H Sludge Supernates of ESP-200.

\begin{tabular}{|c|c|c|c|}
\hline Species & & $\begin{array}{c}\text { Pre-Decant } \\
\text { ESP-200 Supernate }\end{array}$ & $\begin{array}{c}\text { Post-Decant } \\
\text { ESP-200 Supernate }\end{array}$ \\
\hline$\left[\mathrm{NO}_{3}{ }^{-}\right]$ & $M$ & $0.038(10)$ & $0.043(1.9)$ \\
\hline$\left[\mathrm{NO}_{2}^{-}\right]$ & $M$ & $0.18(8.5)$ & $0.16(4.0)$ \\
\hline$\left[\mathrm{SO}_{4}{ }^{2-}\right]$ & $M$ & $0.007(12)$ & $0.007(3.7)$ \\
\hline$\left[\mathrm{C}_{2} \mathrm{O}_{4}{ }^{2-}\right]$ & $M$ & $0.003(1.1)$ & $0.003(2.2)$ \\
\hline$\left[\mathrm{CO}_{3}{ }^{2-}\right]$ & $M$ & $0.051(1.7)$ & $0.054(1.0)$ \\
\hline$\left[\mathrm{AlO}_{2}^{-}\right]$ & $M$ & $0.003(4.2)$ & $0.002(1.9)$ \\
\hline$\left[\mathrm{OH}^{-}\right]_{\mathrm{rree}}$ & $M$ & $0.022(3.1)$ & $0.015(1.3)$ \\
\hline$[\mathrm{Cl}]$ & $M$ & $0.001(22)$ & $0.001(22)$ \\
\hline$[\mathrm{F}]$ & $\mathbf{M}$ & $0.002(3.4)$ & $0.002(5.8)$ \\
\hline $\mathrm{Na}$ & $M$ & $0.38(0.3)$ & $0.40(2.0)$ \\
\hline $\mathbf{K}$ & $M$ & Not Measured & 0.001 \\
\hline $\mathrm{Fe}$ & $\mathrm{mgl}$ & $<1.69$ & $<0.28$ \\
\hline Al & $\mathrm{mg} / \mathrm{L}$ & $67(4.2)$ & $62(1.9)$ \\
\hline$M n$ & $\mathrm{mg} / \mathrm{L}$ & $<0.25$ & $<0.079$ \\
\hline $\mathrm{Mg}$ & $\mathrm{mg} / \mathrm{L}$ & $0.82(33)$ & $<0.064$ \\
\hline $\mathrm{Cr}$ & $\mathrm{mg} / \mathrm{L}$ & $26.7(0.3)$ & $27.4(2.0)$ \\
\hline $\mathbf{P}$ & $\mathrm{mg} / \mathrm{L}$ & $3.26(13)$ & $3.43(4.2)$ \\
\hline $\mathrm{Hg}$ & $\mathrm{mg} / \mathrm{L}$ & Not Measured & $12.2(5.0)$ \\
\hline $\mathrm{Cs}^{137}$ & $\mu \mathrm{Ci} / \mathrm{mL}$ & $2.30(6.1)$ & $2.23(1.0)$ \\
\hline $\mathrm{Sr}^{90}$ & $\mu \mathrm{CV} / \mathrm{mL}$ & Not Measured & $0.008(20)$ \\
\hline$U$ & $\mathrm{mg} / \mathrm{L}$ & Not Measured & $0.40(4.3)$ \\
\hline $\mathrm{Pu}$ & $\mathrm{mg} / \mathrm{L}$ & Not Measured & Not Detected \\
\hline
\end{tabular}

Value in parenthesis indicates percent relative standard deviation of four or more determinations on aliquots of the same sample. This value gives a measure of the analytical precision and does not account for the sampling uncertainty. 
Table 7. Total Dried Solids Composition of the Pre-Decant and Post-Decant Tank $42 \mathrm{H}$ Sludge Sample ESP-200 and the Unwashed Sludge from the 1992 Tank 42H Sludge Sample.

\begin{tabular}{|c|c|c|c|c|}
\hline Species & & $\begin{array}{c}\text { Pre-Decant } \\
\text { ESP-200 Sludge }\end{array}$ & $\begin{array}{l}\text { Post-Decant } \\
\text { ESP-200 Sludge }\end{array}$ & $\begin{array}{c}1992 \text { Unwashed Tank } \\
\text { 42H Sludge* }\end{array}$ \\
\hline $\mathrm{Fe}$ & wt \% & $20.1(4.0)$ & $22.2(4.6)$ & $21.2(5.7)$ \\
\hline $\mathrm{Na}$ & $w t \%$ & $7.99(3.6)$ & $6.94(4.9)$ & $8.52(2.1)$ \\
\hline Al & $w t \%$ & $7.49(5.7)$ & $8.04(3.5)$ & $7.76(4.6)$ \\
\hline $\mathbf{U}$ & $w t \%$ & Not measured & $2.63(3.7)$ & $2.66(3.2)$ \\
\hline$M n$ & $w t \%$ & $3.46(3.8)$ & $3.82(3.8)$ & $\quad 3.52(3.1)$ \\
\hline $\mathrm{Ca}$ & wt \% & $2.15(4.3)$ & $2.41(3.6)$ & $2.20(5.0)$ \\
\hline $\mathrm{Mg}$ & $w t \%$ & $1.12(4.2)$ & $1.25(3.9)$ & $1.23(4.5)$ \\
\hline Si & $w t \%$ & $1.30(3.4)$ & $1.39(1.7)$ & - \\
\hline $\mathrm{Hg}$ & wt \% & Not measured & $1.26(4.4)$ & $0.94(3.9)$ \\
\hline$P$ & wt \% & $0.80(6.6)$ & $0.90(3.3)$ & $0.94(3.3)$ \\
\hline $\mathrm{Ni}$ & $w t \%$ & $0.32(7.4)$ & $0.38(4.5)$ & $0.34(5.9)$ \\
\hline $\mathrm{Cr}$ & $w t \%$ & $0.12(9.0)$ & $0.14(3.8)$ & $0.13(8.2)$ \\
\hline $\mathrm{Cd}$ & wt \% & $0.10(7.0)$ & $0.11(5.6)$ & - \\
\hline$K$ & wt \% & Not measured & $<0.1$ & - \\
\hline $\mathrm{Cu}$ & wt $\%$ & $0.020(15)$ & $0.033(17)$ & $0.027(2.1)$ \\
\hline$\pi$ & $w t \%$ & $0.013(13)$ & $0.019(3.8)$ & $0.016(5.8)$ \\
\hline $\mathrm{Pu}$ & wt \% & Not measured & $0.0085(3.0)$ & $0.0092(1.2)$ \\
\hline $\mathrm{Ag}$ & wt \% & Not measured & $0.036(5.7)$ & $0.015(4.4)$ \\
\hline Pd & $w t \%$ & Not measured & $0.0021(12)$ & $0.0013(1.1)$ \\
\hline Ru & wt $\%$ & Not measured & $0.021(4.9)$ & $0.017(4.7)$ \\
\hline Rh & wt \% & Not measured & $0.0051(6.1)$ & $0.0041(5.5)$ \\
\hline
\end{tabular}


Table 7. (Continued)

\begin{tabular}{llccc} 
Species & & $\begin{array}{c}\text { Pre-Decant } \\
\text { ESP-200 Sludge }\end{array}$ & $\begin{array}{c}\text { Post-Decant } \\
\text { ESP-200 Sludge }\end{array}$ & $\begin{array}{c}1992 \text { Unwashed Tank } \\
\text { 42H Sludge* }\end{array}$ \\
\hline $\mathrm{Sr}^{90}$ & $\mu \mathrm{Ci} / \mathrm{g}$ & Not measured & $4.94 \mathrm{E}+03(5.9)$ & $5.63 \mathrm{E}+03(2.4)$ \\
$\mathrm{Cs}^{137}$ & $\mu \mathrm{Ci} / \mathrm{g}$ & $1.84 \mathrm{E}+02(3.2)$ & $1.94 \mathrm{E}+02(2.5)$ & $1.56 \mathrm{E}+02(3.7)$ \\
$\mathrm{Cm}^{244}$ & $\mu \mathrm{Ci} / \mathrm{g}$ & Not measured & $5.21 \mathrm{E}+00(23)$ & $6.03 \mathrm{E}+00(15)$ \\
$\mathrm{Am}^{241}$ & $\mu \mathrm{Ci} / \mathrm{g}$ & $7.10 \mathrm{E}+00(5.6)$ & $7.39 \mathrm{E}+00(11)$ & $5.86 \mathrm{E}+00(20)$ \\
$\mathrm{Eu}^{154}$ & $\mu \mathrm{Ci} / \mathrm{g}$ & $1.42 \mathrm{E}+01(3.4)$ & $1.53 \mathrm{E}+01(3.2)$ & $1.62 \mathrm{E}+01(2.8)$ \\
$\mathrm{Eu}^{155}$ & $\mu \mathrm{Ci} / \mathrm{g}$ & $2.00 \mathrm{E}+00(10)$ & $1.98 \mathrm{E}+00(18)$ & $3.12 \mathrm{E}+00(8.1)$ \\
$\mathrm{Co}^{60}$ & $\mu \mathrm{Ci} / \mathrm{g}$ & $8.10 \mathrm{E}-01(6.8)$ & $8.62 \mathrm{E}-01(2.0)$ & $1.55 \mathrm{E}+00(11)$ \\
$\mathrm{Np}^{237}$ & $\mu \mathrm{Ci} / \mathrm{g}$ & Not measured & $1.37 \mathrm{E}-02(8.6)$ & - \\
$\mathrm{Ru}^{108}$ & $\mu \mathrm{Ci} / \mathrm{g}$ & Not measured & $<2.6 \mathrm{E}+00$ & - \\
$\mathrm{Sb}^{125}$ & $\mu \mathrm{Ci} / \mathrm{g}$ & Not measured & $<1.2 \mathrm{E}+00$ & - \\
$\mathrm{Ce}^{144}$ & $\mu \mathrm{Ci} / \mathrm{g}$ & Not measured & $<2.3 \mathrm{E}+00$ & - \\
$\mathrm{Te}^{125 \mathrm{~m}}$ & $\mu \mathrm{Ci} / \mathrm{g}$ & Not measured & $<1.2 \mathrm{E}+00$ & - \\
$\mathrm{Alpha}_{\text {Tolal }}$ & $\mu \mathrm{Ci} / \mathrm{g}$ & Not measured & $1.09 \mathrm{E}+02(2.8)$ & - \\
$\mathrm{Beta}_{\text {Total }}$ & $\mu \mathrm{Ci} / \mathrm{g}$ & Not measured & $1.26 \mathrm{E}+04(4.2)$ & - \\
& & & & -
\end{tabular}

* The composition for the 1992 unwashed Tank 42H sludge sample comes from reference 12.

Value in parenthesis indicates percent relative standard deviation of four or more determinations on aliquots of the same sample. This value gives a measure of the analytical precision and does not account for the sampling uncertainty. 
Table 8. Uranlum and Plutonium Isotopics from Total Dried Solids Analysis of the PostDecant Tank 42H Sludge Sample ESP-200 and the Unwashed Sludge from the 1992 Tank 42H Sludge Sample.

\begin{tabular}{|c|c|c|c|}
\hline Isotope & & $\begin{array}{l}\text { Post-Decant } \\
\text { ESP-200 Sludge }\end{array}$ & $\begin{array}{c}1992 \text { Unwashed Ta } \\
42 \mathrm{H} \text { Sludge }\end{array}$ \\
\hline \multicolumn{4}{|c|}{ Isotopic Distribution as Weight Percent of Total Dried Solids } \\
\hline $\mathrm{U}^{233}$ & $w t \%$ & $3.98 \mathrm{E}-04$ (13) & $2.86 \mathrm{E}-04(2.0)$ \\
\hline$U^{234}$ & $w t \%$ & 4.38E-04 (13) & 3.09E-04 (3.2) \\
\hline$U^{235}$ & $w t \%$ & $1.59 E-02(6.1)$ & $1.48 \mathrm{E}-02(2.4)$ \\
\hline $\mathrm{U}^{236}$ & wt \% & $1.44 E-03(8.0)$ & $1.23 E-03(2.4)$ \\
\hline$U^{238}$ & wt \% & $2.62 E+00(3.6)$ & $2.64 E+00(3.2)$ \\
\hline$U^{\text {lotal }}$ & $w t \%$ & $2.63 E+00(3.7)$ & $2.66 E+00(3.2)$ \\
\hline $\mathrm{Pu}^{238}$ & wt $\%$ & 5.37E-04 (3.0) & $5.14 E-04(11)$ \\
\hline $\mathrm{Pu}^{239}$ & $w t \%$ & $7.13 E-03(2.8)$ & $7.00 E-03(3.4)$ \\
\hline $\mathrm{Pu}^{240}$ & wt \% & 6.97E-04 (9.9) & 5.79E-04 (3.7) \\
\hline $\mathrm{Pu}^{241}$ & wt \% & 2.90E-05 (4.0) & $4.57 E-05(52)$ \\
\hline $\mathrm{Pu}^{242}$ & wt \% & 7.42E-05 (33) & 7.73E-05 (2.6) \\
\hline $\mathrm{Pu}^{10+21}$ & $w t \%$ & $8.47 E-03(3.0)$ & $8.20 E-03(3.4)$ \\
\hline
\end{tabular}

Isotopic Distribution as Percent of Total Uranium and Plutonium

$\begin{array}{llc}\mathrm{U}^{233} & 0.015(9.0) & 0.011(5.0) \\ \mathrm{U}^{234} & 0.017(12) & 0.012(6.4) \\ \mathrm{U}^{235} & 0.60(2.7) & 0.56(5.5) \\ \mathrm{U}^{236} & 0.055(5.0) & 0.046(5.6) \\ \mathrm{U}^{230} & 99.3(0.1) & 99.4(0.1) \\ \mathrm{Pu}^{239} & & \\ \mathrm{Pu}^{239} & 6.34(3.2) & 6.27(12) \\ \mathrm{Pu}^{240} & 84.2(0.8) & 85.4(1.1) \\ \mathrm{Pu}^{241} & 8.22(8.8) & 7.06(1.0) \\ \mathrm{Pu}^{242} & 0.35(3.8) & 0.55(48) \\ & 0.87(30) & 0.94(2.2)\end{array}$

* The composition for the 1992 unwashed Tank 42H sludge sample comes from reference 12.

Value in parenthesis indicates percent relative standard deviation of four or more determinations on aliquots of the same sample. This value gives a measure of the analytical precision and does not account for the sampling uncertainty. 
WSRC-RP-98-00406

Page 19 of 24 .

Table 9. Insoluble Solids* Composition of the Post-Decant Tank 42H Sludge Sample ESP. 200.

\begin{tabular}{llcc} 
Species & & $\begin{array}{c}\text { Post-Decant } \\
\text { ESP-200 Sludge } \\
\text { Insoluble Solids }\end{array}$ & $\begin{array}{c}\text { Ratio to Post-Decant } \\
\text { ESP-200 Sludge } \\
\text { Total Dried Solids }\end{array}$ \\
\hline $\mathrm{Fe}$ & $w t \%$ & $25.6(2.3)$ & 1.15 \\
$\mathrm{Na}$ & $w t \%$ & $2.63(2.2)$ & 0.38 \\
$\mathrm{Al}$ & $w t \%$ & $8.78(1.6)$ & 1.09 \\
$\mathrm{Mn}$ & $w t \%$ & $4.36(2.7)$ & 1.14 \\
$\mathrm{Ca}$ & $w t \%$ & $2.74(2.6)$ & 1.14 \\
$\mathrm{Mg}$ & $w t \%$ & $1.43(2.7)$ & 1.14 \\
$\mathrm{P}$ & $w t \%$ & $1.01(2.0)$ & 1.12 \\
$\mathrm{Ni}$ & $w t \%$ & $0.42(2.3)$ & 1.11 \\
$\mathrm{Cr}$ & $w t \%$ & $0.13(2.3)$ & 0.93 \\
$\mathrm{Cd}$ & $w t \%$ & $0.13(2.5)$ & 1.18 \\
$\mathrm{Cu}$ & $w t \%$ & $0.032(3.9)$ & 0.97 \\
$\mathrm{Ti}$ & $w t \%$ & $0.017(3.1)$ & 0.90
\end{tabular}

*The insoluble solids composition results from washing an aliquot of the sludge sample with large volumes of water to remove soluble material.

Value in parenthesis indicates percent relative standard deviation of four or more determinations on aliquots of the same sample. This value gives a measure of the analytical precision and does not account for the sampling uncertainty. 
Table 10. Estimated Composition of ESP-190 and Post-Decant ESP-200 decanted to 100 inches Compared with the Measured Composition of Post-Decant ESP-200.

\begin{tabular}{|c|c|c|c|c|}
\hline Species & & $\begin{array}{c}\text { Estimated } \\
\text { Composition } \\
\text { of ESP-190 } \\
\text { Decanted to } \\
100 \text { in. }\end{array}$ & $\begin{array}{c}\text { Estimated } \\
\text { Composition } \\
\text { of ESP-200 } \\
\text { Decanted to } \\
100 \text { in. }\end{array}$ & $\begin{array}{c}\text { Measured } \\
\text { Composition of } \\
\text { Post-Decant } \\
\text { ESP-200 } \\
\end{array}$ \\
\hline $\mathrm{Na}$ & wt $\%$ & 7.00 & 5.42 & 6.94 \\
\hline $\mathrm{Fe}$ & wt \% & 20.1 & 21.7 & 22.2 \\
\hline Al & wt \% & 7.60 & 8.06 & 8.04 \\
\hline $\mathrm{Mn}$ & wt \% & 3.47 & 3.72 & 3.84 \\
\hline $\mathrm{Ca}$ & wt \% & 2.53 & 2.32 & 2.41 \\
\hline $\mathrm{Mg}$ & wt \% & 1.15 & 1.21 & 1.25 \\
\hline $\mathrm{Si}$ & wt \% & 1.31 & 1.40 & 1.38 \\
\hline$P$ & $w t \%$ & 0.72 & 0.86 & 0.90 \\
\hline $\mathrm{Ni}$ & $w t \%$ & 0.40 & 0.34 & 0.38 \\
\hline $\mathrm{Cr}$ & $w t \%$ & 0.17 & 0.13 & 0.14 \\
\hline Sp. G. of Supernate & $\mathrm{g} / \mathrm{mL}$ & 1.02 & 1.02 & 1.02 \\
\hline Sp. G. of Slurry & $\mathrm{g} / \mathrm{mL}$ & 1.16 & 1.17 & 1.13 \\
\hline wt \% Total Solids & & 19.9 & 21.3 & 16.0 \\
\hline wt \% Dissolved Solids & & 2.67 & 2.51 & 2.29 \\
\hline wt \% Insoluble Solids & & 17.8 & 19.3 & 14.1 \\
\hline wt \% Soluble Solids & & 2.10 & 1.94 & 1.97 \\
\hline
\end{tabular}


Table 11. Estimated Current Composition of Tank 42H Sludge Decanted to 100 inches.

\begin{tabular}{|c|c|c|}
\hline Species & & $\begin{array}{c}\text { Estimated Composition of } \\
\text { Tank } 42 \mathrm{H} \text { Sludge } \\
\text { Decanted to } 100 \text { inches } \\
\end{array}$ \\
\hline \multicolumn{3}{|c|}{ Supernate* } \\
\hline$\left[\mathrm{NO}_{3}^{-}\right]$ & $M$ & 0.052 \\
\hline$\left[\mathrm{NO}_{2}^{-}\right]$ & M & 0.21 \\
\hline$\left[\mathrm{SO}_{4}^{2-}\right]$ & $M$ & 0.009 \\
\hline$\left[\mathrm{PO}_{4}{ }^{3}\right]$ & $M$ & 0.0001 \\
\hline$\left[\mathrm{C}_{2} \mathrm{O}_{4}^{2-}\right]$ & $M$ & 0.003 \\
\hline$\left[\mathrm{CO}_{3}{ }^{2-}\right]$ & $M$ & 0.065 \\
\hline$\left[\mathrm{AlO}_{2}^{-}\right]$ & $M$ & 0.003 \\
\hline$\left[\mathrm{OH}^{-}\right]_{\mathrm{ires}}$ & $M$ & 0.022 \\
\hline$\left[\mathrm{Cl}^{\prime}\right]$ & $M$ & 0.001 \\
\hline$[F]$ & $M$ & 0.003 \\
\hline $\mathrm{Na}$ & $M$ & 0.45 \\
\hline $\mathrm{Cr}$ & $\mathrm{mg} / \mathrm{L}$ & 29.8 \\
\hline $\mathrm{Hg}$ & $\mathrm{mg} / \mathrm{L}$ & 2.6 \\
\hline $\mathrm{U}$ & $\mathrm{mg} / \mathrm{L}$ & 0.4 \\
\hline $\mathrm{Pu}$ & $\mathrm{mg} / \mathrm{L}$ & 0.0005 \\
\hline $\mathrm{Cs}^{137}$ & $\mu \mathrm{Ci} / \mathrm{mL}$ & 2.97 \\
\hline$S r^{90}$ & $\mu \mathrm{Ci} / \mathrm{mL}$ & 0.008 \\
\hline Sp. g. & $\mathrm{g} / \mathrm{mL}$ & 1.02 \\
\hline \multicolumn{2}{|c|}{$\begin{array}{l}\text { Wt \% Dissolved } \\
\text { Solids }\end{array}$} & 2.59 \\
\hline
\end{tabular}

The estimated supernate composition is the average of the supernate compositions from Tank $42 \mathrm{H}$ dip samples ESP-190, ESP-191, and ESP-199. Not all analyses were conducted on every sample. For example, U, Pu and $\mathrm{Sr}^{\circ 0}$ were only measured in ESP-191. 
Table 11. (Continued)

\begin{tabular}{|c|c|c|}
\hline \multicolumn{2}{|c|}{ Species } & $\begin{array}{c}\text { Estimated Composition of } \\
\text { Tank } 42 \mathrm{H} \text { Sludge } \\
\text { Decanted to } 100 \text { inches }\end{array}$ \\
\hline \multicolumn{3}{|c|}{ Total Dried Solids ${ }^{\star \star}$} \\
\hline $\mathrm{Fe}$ & wt \% & 22.2 \\
\hline $\mathrm{Na}$ & wt \% & 6.94 \\
\hline $\mathrm{Al}$ & $w t \%$ & 8.04 \\
\hline$U$ & $w t \%$ & 2.63 \\
\hline$M n$ & $w t \%$ & 3.82 \\
\hline $\mathrm{Ca}$ & wt \% & 2.41 \\
\hline$M g$ & wt \% & 1.25 \\
\hline $\mathrm{Si}$ & $w t \%$ & 1.39 \\
\hline $\mathrm{Hg}$ & $w t \%$ & 1.26 \\
\hline$P$ & $w t \%$ & 0.90 \\
\hline $\mathrm{Ni}$ & wt $\%$ & 0.38 \\
\hline $\mathrm{Cr}$ & $w t \%$ & 0.14 \\
\hline $\mathrm{Cd}$ & wt \% & 0.11 \\
\hline K & wt \% & $<0.1$ \\
\hline $\mathrm{Cu}$ & wt \% & 0.033 \\
\hline $\mathrm{Ti}$ & wt $\%$ & 0.019 \\
\hline $\mathrm{Pu}$ & $w t \%$ & 0.0085 \\
\hline $\mathrm{Ag}$ & $w t \%$ & 0.036 \\
\hline Pd & wt \% & 0.0021 \\
\hline Ru & $w t \%$ & 0.021 \\
\hline Rh & wt \% & 0.0051 \\
\hline Sp. g. & $\mathrm{g} / \mathrm{mL}$ & 1.16 \\
\hline $\begin{array}{l}\text { Wt } \% 7 \\
\text { Solids }\end{array}$ & & 19.9 \\
\hline $\begin{array}{l}\text { Wt \% I } \\
\text { Solids }\end{array}$ & & 17.8 \\
\hline $\begin{array}{l}\text { Wt \% } \\
\text { Solids }\end{array}$ & & 2.10 \\
\hline
\end{tabular}


Table 11. (Continued)

\section{Estimated Composition of}

Tank 42H Sludge

Species

Decanted to 100 inches

Total Dried Solids ${ }^{\star \star}$

$\mathrm{Sr}^{\circ 0}$

$\mu \mathrm{Ci} / \mathrm{g}$

4.94E+03

$\mathrm{Cs}^{137} \quad \mu \mathrm{Ci} / \mathrm{g}$

$1.94 E+02$

$\mathrm{Cm}^{244}$

$\mu \mathrm{Ci} / \mathrm{g}$

$5.21 E+00$

$\mathrm{Am}^{241}$

$\mu \mathrm{Ci} / \mathrm{g}$

$7.39 \mathrm{E}+00$

$\mathrm{Eu}^{154}$

$\mu \mathrm{Ci} / \mathrm{g}$

$1.53 \mathrm{E}+01$

$E u^{155}$

$\mu \mathrm{Ci} / \mathrm{g}$

$1.98 \mathrm{E}+00$

$\mathrm{Co}^{50}$

$\mu \mathrm{Civg}$

8.62E-01

$\mathrm{Np}^{237}$

$\mu \mathrm{Ci} / \mathrm{g}$

1.37E-02

$\mathrm{Ru}^{106}$

$\mu \mathrm{Ci} / \mathrm{g}$

$<2.6 \mathrm{E}+00$

$\mathrm{Sb}^{125}$

$\mu \mathrm{Ci} / \mathrm{g}$

$<1.2 \mathrm{E}+00$

$\mathrm{Ce}^{144} \cdot \quad \mu \mathrm{Ci} / \mathrm{g}$

$<2.3 E+00$

$\mathrm{Te}^{125 m}$

$\mu \mathrm{Ci} / \mathrm{g}$

$<1.2 E+00$

Alpha $_{\text {Total }}$

$\mu \mathrm{Ci} / \mathrm{g}$

$1.09 \mathrm{E}+02$

Beta $_{\text {Total }}$

$\mu \mathrm{Ci} / \mathrm{g}$

$1.26 \mathrm{E}+04$

$U^{233}$

wt \%

3.98E-04

$\mathrm{U}^{234}$

$w t \%$

4.38E-04

$\mathrm{U}^{235}$

wt \%

1.59E-02

$\mathrm{U}^{236}$

$w t \%$

1.44E-03

$\mathrm{U}^{238}$

wt \%

$2.62 E+00$

$U^{\text {total }}$

wt \%

$2.63 E+00$

$\mathrm{Pu}^{238}$

wt \%

5.37E-04

$\mathrm{Pu}^{239}$

wt \%

7.13E-03

$\mathrm{Pu}^{240}$

wt \%

6.97E-04

$\mathrm{Pu}^{241}$

wt \%

2.90E-05

$\mathrm{Pu}^{242}$

wt $\%$

7.42E-05

Putoal

wt \%

8.47E-03

**The estimated composition of the total dried solids was taken from the measured composition of Post-Decant ESP-200 (Tables 6-8). The weight percent solids and specific gravity of the sludge slurry were taken from estimated composition of ESP-190 decanted to 100 inches (Table 10). 


\section{Distribution}

M. K. Andrews, 773-A

D. A. Barber, 241-120H

T. E. Britt, 703-H

K. G. Brown, 704-1T

M. C. Chandler, 703-H

A. S. Choi, 704-1T

C. J. Coleman, 773-A

C. L. Crawford, 773-41A

N. R. Davis, 719-4A

W. E. Daniels, 704-1T

R. E. Edwards, 704-25S

H. H. Elder, 704-S

T. L. Fellinger, 773-A

S. D. Fink, 773-A

C. R. Goetzman, 773-A

J. R. Harbor, 773-43A

J. R. Hester, 703-H

D. T. Hobbs, 773-A

E. W. Holtzscheiter, 773-A

R. A. Jacobs, 704T

M. D. Johnson, 703-H

D. P. Lambert, 704-1T

L. F. Landon, 704-T

E. D. Lee, 241-152H

B. L. Lewis, 703-H

T. J. Lex, 703-H

S. L. Marra, 704-25S

K. M. Marshall, 773-A

M. S. Miller, 704-56H

J. E. Occhipinti, 704-27S

J. F. Ortaldo, 704-S

T. L. Ortner, 241-152H

S. F. Piccolo, 704-3N

M. R. Poirier, 676-T

W. L. Tamosaitis, 773-A

D. D. Walker, 773-A

W. R. Wilmarth, 773-42A

WPT-LWG Files, 773-A

$\operatorname{TIM}(4), 703-43 A$

Record Administration, 773-52A 